УДК 342.9

DOI https:/ / doi.org/10.32837/yuv.v0i2.1727

А. Цабека,

аспірант кафедри кримінально-правових дисциплін та судочинства

Навчально-наукового інституту права

Сумського державного університету

\title{
РЕФОРМУВАННЯ АДМІНІСТРАТИВНО- ТЕРИТОРІАЛЬНОГО УСТРОЮ ДЕРЖАВИ В УМОВАХ ДЕЦЕНТРАЛІЗАЦІї ОРГАНІВ ВИКОНАВЧОЇ ВЛАДИ В УКРАЇНІ
}

Приєднання України до Європейської хартії місцевого самоврядування шляхом ратифікації 15 липня 1997 року ознаменувало запровадження стратегічного курсу розвитку демократичної держави, реалізація якого вимагає створення дієвої та передової нормативно-правової бази, зокрема з урегулювання питань у сфері децентралізації органів виконавчої влади. Водночас серед пріоритетних завдань сучасного процесу децентралізації органів виконавчої влади, що відбуваються в Україні, важливе місце відведено створенню нового спроможного адміністративно-територіального устрою. Саме формування ефективної системи територіальної організації влади може сприяти створенню нових можливостей надання якісних та доступних публічних послуг на найбільш наближеному до людей рівні, соціально-економічному розвитку окремих територій та розширенню прав на місцевому рівні тощо. Однак реалізаціі всіх завдань, котрі сьогодні в межах децентралізації органів виконавчої влади в Україні визнані стратегічними, є неможливою за відсутності нормативно-правового акта, нормами якого має бути визначено та врегульовано питання щодо адміністративнотериторіального устрою.

Питання щодо особливостей децентралізації органів виконавчої влади в Україні, викликів та проблем, сучасного стану тощо неодноразово вивчались вітчизняними дослідниками, серед яких
О.І. Васильєва, В.С. Куйбіда, А.П. Лелеченко, А.М. Нікончук, А.Ф. Ткачук, M.M. Трещов, I.В. Хребтій, Н.В. Янюк та інші. Багато наукових праць також присвячено й дослідженню основоположних засад реформування адміністративно-територіального устрою держави, серед яких Л.А. Білуха, А.С. Дем'янченко, О.І. Дем'янчук, Ю.С. Малько, О.І. Новікова, О.В. Стогова, Н.В. Фоміцька тощо. Водночас науковий інтерес у межах тематики дослідження становить саме комплексне вивчення питань реформування адміністративно-територіального устрою держави в умовах децентралізації органів виконавчої влади в Україні.

Мета статті - дослідити цілі, особливості та визначальні засади реформування адміністративно-територіального устрою держави в умовах децентралізації органів виконавчої влади в Україні.

Комплексна реформа децентралізації органів виконавчої влади має важливими завданнями впорядкування адміністративно-територіального устрою та вдосконалення системи організації влади. Потреба прийняття законодавчого акта, який повинен визначати загальні засади впорядкування адміністративно-територіального устрою країни, першочергово закріплена на конституційному рівні. Зокрема, ст. 92 Конституції України встановлено, що територіальний устрій України визначається виключно законом [3]. 
Зазначимо, що перший Проєкт Закону про засади адміністративно-територіального устрою України № 8051 було зареєстровано 22 лютого 2018 року (далі - Законопроєкт № 8051). Законопроєкт № 8051 визначав засади адміністративно-територіального устрою України, порядок утворення, ліквідації, встановлення і зміни меж адміністративно-територіальних одиниць. Також у поданому Законопроєкті № 8051 пропонувалось прийняття Закону України «Про адміністративно-територіальний устрій України», яким буде визначено перелік та склад адміністративно-територіальних одиниць [9]. Однак майже через півтора року (29 серпня 2019 року), законопроєкт було знято з розгляду. Зокрема, в зауваженнях щодо Законопроєкту № 8051, викладених у Висновку Головного науково-експертного управління від 18 травня 2018 року, ідея щодо прийняття одночасно двох законодавчих актів у сфері регулювання адміністративно-територіального устрою була визнана необгрунтованою [2].

3 урахуванням всіх зауважень, зроблених до Законопроєкту № 8051, на початку 2020 року до Верховної Ради України було направлено новий Проєкт Закону про засади адміністративно-територіального устрою України, зареєстрований за № 2804 від 24 січня 2020 року (далі - Законопроєкт № 2804). Основною метою його прийняття визнано необхідність законодавчого визначення основних засад адміністративно-територіального устрою України, порядку утворення, ліквідації, встановлення і зміни меж адміністративно-територіальних одиниць та населених пунктів [8]. Важливо звернути увагу, що, на відміну від Законопроєкту № 8051, у тексті Законопроєкту № 2804 було вилучено текст щодо розробки та прийняття Закону України «Про адміністративно-територіальний устрій України». Але, незважаючи на те, що завершення адміністративно-територіальної реформи мало відбутись до квітня 2020 року, 4 березня Зако- нопроєкт № 2804 відкликано та знято з розгляду (відповідно до інформації на офіційному веб-сайті Верховної Ради України). Нового Законопроєкту щодо впорядкування адміністративно-територіального устрою на сьогодні не зареєстровано.

Ураховуючи зазначене, вбачається доцільним визначити цілі реформування адміністративно-територіального устрою держави в контексті децентралізації, а також розглянути загальні засади проведення цієї реформи.

Із метою визначення основних цілей реформування адміністративно-територіального устрою держави в контексті децентралізації виконавчої влади необхідно звернутись до Концепції реформування місцевого самоврядування та територіальної організації влади в Україні. Прямо вони не визначені, але з аналізу положень Концепції [7] серед основних цілей проведення реформи можна визначити такі:

1) формування нової системи адміністративно-територіального устрою держави;

2) розмежування повноважень (оптимальний розподіл) між органами місцевого самоврядування та органами виконавчої влади на різних рівнях адміністративно-територіального устрою;

3) формування критеріїв для адміністративно-територіальних одиниць різного рівня адміністративно-територіального устрою держави.

Головним органом у системі центральних органів виконавчої влади, який забезпечує формування та реалізує державну регіональну політику, державну політику у сфері розвитку місцевого самоврядування, територіальної організації влади та адміністративно-територіального устрою, є Міністерство розвитку громад та територій України (далі - Мінрегіон). Основні питання щодо діяльності та правового статусу Мінрегіону на законодавчому рівні визначені у відповідному Положенні, затвердженому постановою Кабінету Міністрів України від 30 квітня 2014 року № 197 [5]. Серед 
визначених у законодавстві завдань Мінрегіону важливе значення має забезпечення формування адміністративно-територіального устрою та формування спроможних територіальних громад.

У Концепції реформування місцевого самоврядування та територіальної організації влади в Україні передбачено трирівневу структуру побудови адміністративно-територіального устрою, a caмe:

1) базовий рівень (адміністративно-територіальні одиниці - громади);

2) районний рівень (адміністративно-територіальні одиниці - райони);

3) регіональний рівень (адміністративно-територіальні одиниці - Автономна Республіка Крим, області, мм. Київ і Севастополь) [7].

У контексті реформування адміністративно-територіального устрою країни визначено, що його базовий рівень має бути представлений відповідними адміністративно-територіальними одиницями - громадами. Зокрема, в Законопроєкті № 2804 громаду запропоновано визначати як адміністративно-територіальну одиницю базового рівня, до складу якої входять один або декілька населених пунктів. Водночас громада $€$ просторовою основою для здійснення місцевого самоврядування територіальними громадами як безпосередньо, так і через відповідні органи місцевого самоврядування [8].

Систему адміністративно-територіального устрою України визначено на конституційному рівні у ст. 133 Конституції України. Ії становлять: Автономна Республіка Крим, області, райони, міста, райони в містах, селища й села [3]. Отже, серед зазначених елементів системи адміністративно-територіального устрою такий базовий елемент як «громада» не визначений. Уведення цього елементу до системи адміністративно-територіального устрою нормами звичайного закону $€$ неприйнятним. Зауважимо, що про це, зокрема, було наголошено у відповідному Висновку Головного науково-експертного управ- ління від 2 березня 2020 року до проєкту Закону України «Про засади адміністративно-територіального устрою України» № 2804 від 24 січня 2020 року [1]. Уведення громади як одиниці адміністративно-територіального устрою можливо лише за умови першочергового внесення відповідних змін до Конституції України як основоположного законодавчого документу, яким це має бути визначено.

Також важливо звернути увагу й на визначення громади, що пропонується закріпити на законодавчому рівні як адміністративно-територіальна одиниця базового рівня, до складу якої входять один або декілька населених пунктів [8]. У ст. 6 Закону України «Про місцеве самоврядування в Україні» територіальна громада визначена як первинний суб'єкт місцевого самоврядування, основний носій його функцій та повноважень. Водночас громадам надається право об'єднання в одну сільську, селищну, міську територіальну громаду, утворення єдиних органів місцевого самоврядування та обрання, відповідно, сільського, селищного, міського голови [6]. Запропоноване в новому законодавчому акті поняття «громада» схоже 3 уже існуючим та закріпленим на рівні законодавства «територіальна громада». Однак із доцільністю введення такого терміну, змістовне наповнення якого відрізняється від уже існуючого, до кінця не можна погодитись. Адже не виключається водночас можливість подальшого перекрученого його сприйняття та неправильного розуміння.

На сучасному етапі в межах реформування адміністративно-територіального устрою держави важливе місце відведено формуванню адміністративно-територіальних одиниць субрегіонального (районного) рівня. На виконання Плану заходів із реалізації нового етапу реформування місцевого самоврядування та територіальної організації влади в Україні на 20192021 роки та з огляду на компетенції Мінрегіону, цим державним органом 
було розроблено відповідні Методичні рекомендації щодо критеріїв формування адміністративно-територіальних одиниць субрегіонального (районного) рівня (далі - Методичні рекомендаціi). Методичні рекомендації містять основні вимоги, характеристики, умови та критерії до адміністративно-територіальних одиниць субрегіонального (районного) рівня, їх адміністративних центрів, меж та складу під час ї формування [4]. Зокрема, в Методичних рекомендаціях надано визначення одиниці адміністративно-територіального устрою субрегіонального (районного) рівня (OCP) та адміністративного центру ОСР; установлено критерії, яким має відповідати ОСР; послідовність визначення адміністративних центрів ОСР тощо.

Важливо зазначити, що в межах реформи децентралізації ще у 2007 році було започатковано швейцарсько-український проєкт «Підтримка децентралізації в Україні» DESPRO - проєкт міжнародної технічної допомоги, котрий працює у сфері реформи місцевого самоврядування в Україні. Проєкт фінансується Швейцарською Конфедерацією через Швейцарську агенцію розвитку та співробітництва (ШБС / SDC) та впроваджується Швейцарським Центром ресурсів та консультацій із питань розвитку (Skat). Місія DESPRO полягає в такому: підтримці реформи місцевого самоврядування; сприянні розвитку місцевого самоврядування через оптимізацію системи управління та підтримку ефективного місцевого розвитку в Україні. Варто зазначити, що DESPRO продовжує інтенсивну підтримку децентралізаційних процесів у тісній співпраці 3 органами місцевого самоврядування, Верховною Радою України, Міністерством розвитку громад та територій України, Міністерством енергетики та захисту довкілля України, Національним агентством України 3 питань державної служби, профільними асоціаціями. Упровадження проєкту DESPRO має так звані чотири фази. На сьогодні від- бувається реалізація Фази IV (20172020 роки), що передбачає публічні обговорення реформи місцевого самоврядування та територіальної організації влади; широкий комунікаційний супровід реформи [11].

За сприяння Швейцарсько-українського проєкту «Підтримка децентралізації в Україні» DESPRO наприкінці березня - початку квітня 2020 року було проведено низку відеоконференцій щодо формування адміністративно-територіальних одиниць субрегіонального рівня. Головною метою проведення таких відеоконференцій стало надання всім областям України онлайн-консультацій із формування нових районів. У такий спосіб була надана можливість усім областям висловити власні пропозиції зі створення субрегіонального рівня адміністративно-територіального устрою. Надані пропозиції всіх обласних державних адміністрацій щодо створення районів у відповідних областях у квітні 2020 року підлягають доопрацюванню з метою започаткування розробки відповідного законопроєкту [10].

Таким чином, процес формування адміністративно-територіальних одиниць субрегіонального рівня сьогодні триває. Водночас у процесі розробки кожною обласною державною адміністрацією пропозицій до формування адміністративно-територіальних одиниць відповідної області дотримуються вимог Методичних рекомендацій, розроблених Мінрегіоном. Водночас запропоновані Методичні рекомендації мають виключно інформаційний характер та не встановлюють норм права, про що безпосередньо в них зазначено. Процес формування адміністративно-територіальних одиниць субрегіонального рівня першочергово має відбуватись відповідно до вимог законодавчого акта. За своєю правовою природою Методичним рекомендаціям притаманний рекомендаційний, роз'яснювальний характер, а тому і їх підготовка, i розробка має зважати на норми нормативно-правового акта. Як уже було 
зазначено, сьогодні законодавчого акта 3 урегулювання питань адміністративно-територіального устрою держави не затверджено. Питання щодо тлумачення поняття району, а також організаційні питання, принципи та порядок визначення адміністративних центрів районів тощо повинні бути визначені в законодавчому акті.

Формування нового адміністративно-територіального устрою районного (субрегіонального) рівня та, відповідно, створення адміністративних округів $є$ основою для майбутніх регіонів. Відповідно до реформування адміністративно-територіального устрою держави адміністративно-територіальними одиницями регіонального рівня (регіонами) пропонується визнати Автономну Республіку Крим, області.

Окрему увагу необхідно звернути на визначення адміністративно-територіальними одиницями зі спеціальним статусом міст Києва та Севастополя. Водночас реформування адміністративно-територіального устрою вимагає необхідність додаткового ухвалення окремих законів України, якими мають бути визначені особливості здійснення державної влади та місцевого самоврядування на території зазначених міст. На сьогодні є чинним Закон України «Про столицю України - місто-герой Київ» від 15 січня 1999 року № 401-XIV. Натомість у чинній українській законодавчій базі відсутній окремий законодавчий акт, яким мають визначатись питання здійснення виконавчої влади та місцевого самоврядування в місті Севастополі. Таким чином, у новому Законі України «Про засади адміністративно-територіального устрою України» необхідним є визначення особливостей міст зі спеціальним статусом як адміністративно-територіальних одиниць.

Також необхідно звернути увагу, що в Концепції реформування місцевого самоврядування та територіальної організації влади в Україні одним з елементів трирівневої структури побудови адміністративно-територіального устрою $є$ регіональний рівень, представлений такими адміністративно-територіальними одиницями: Автономна Республіка Крим, області, міста Київ і Севастополь. У Законопроєкті № 2804 визначено, що адміністративно-територіальними одиницями регіонального рівня є Автономна Республіка Крим та області. Натомість міста Київ і Севастополь визначаються як адміністративно-територіальні одиниці зі спеціальним статусом, тобто вони не віднесені до складу регіонального рівня.

Ураховуючи проведене дослідження в межах досліджуваного питання, можна стверджувати, що реформування адміністративно-територіального устрою держави в умовах проведення децентралізації має за основу сукупність визначальних засад, до яких необхідно віднести такі:

1) створення громад із метою формування базового рівня у структурі адміністративно-територіального устрою;

2) формування адміністративно-територіальних одиниць субрегіонального рівня, котрі становлять районний рівень структури побудови адміністративно-територіального устрою;

3) установлення межі відповідних адміністративно-територіальних одиниць у структурі адміністративно-територіального устрою держави.

у статті досліджено питання реформування адміністративно-територіального устрою держави в умовах децентралізації органів виконавчої влади в Україні. Окрему увагу приділено Проєктам Закону про засади адміністративно-територіального устрою України, поданих до Верховної Ради України та зареєстрованих за № 8051 від 22 лютого 2018 року та № 2804 від 24 січня 2020 року. 3 аналізу окремих положень Концепції реформування місцеевого самоврядування та територіальної організацї влади в Україні визначено чілі реформування адміністративно-територіального устрою держави в контексті децентралізації, до яких віднесено: 
1) формування нової системи адміністративно-територіального устрою держави;

2) розмежування повноважень (оптимальний розподіл) між органами місцевого самоврядування та органами виконавчої влади на різних рівнях адміністративно-територіального устрою;

3) формування критеріїв для адміністративно-територіальних одиниць різного рівня адміністративно-територіального устрою держави.

Розглянуто трирівневу структуру побудови адміністративно-територіального устрою (базовий, районний та регіональний рівні). Шляхом визначення конституиійно встановленої системи адміністративно-територіального устрою України з'ясовано проблемні аспекти введення до такої системи нового елеменmу - громади, а також доиільність уведення такого терміну до законодавства. Висвітлено особливості Швейцарсько-українського проєкту «Підтримка децентралізації в Україні» DESPRO у сприянні проведення реформи децентралізації в Україні. Звернено увагу на особливості формування адміністративно-територіальних одиницьь відповідної області із дотриманням вимог, Методичні рекомендації щодо критерії формування адміністративно-територіальних одиниць субрегіонального (районного) рівня. Визначено базові засади реформування адміністративно-територіального устрою держави в умовах проведення децентралізації в Україні.

Ключові слова: децентралізація, адміністративно-територіальний устрій, органи виконавчої влади, місцеве самоврядування, територіальна громада.

Tsabeka A. Reforming of the administrative-territorial structure of the state in the context of decentralization of executive authorities in Ukraine
The article examines the issue of reforming the administrative-territorial structure of the state in the context of decentralization of executive authorities in Ukraine. Particular attention is paid to the Draft Law on the Principles of Administrative and Territorial Organization of Ukraine, submitted to the Verkhouna Rada of Ukraine and registered for № 8051 dated February 22, 2018 and № 2804 dated January 24 , 2020. From the analysis of certain provisions of the Concept of reforming local self-government and territorial organization of power in Ukraine, the goals of reforming the administrativeterritorial structure of the state in the context of decentralization are determined, which include: 1) formation of a new system of administrativeterritorial organization; 2) separation of powers (optimal distribution) between local governments and executive authorities at different levels of administrative-territorial organization; 3) formation of criteria for administrative-territorial units of different levels of administrativeterritorial structure of the state. The three-level structure of construction of administrative-territorial system (basic, district and regional levels) is considered. By defining the constitutionally established system of administrative-territorial organization of Ukraine, the problematic aspects of introducing a new element into such a system - the community, as well as the feasibility of introducing such a term into the legislation. The peculiarities of the Swiss-Ukrainian project "Support to Decentralization in Ukraine" DESPRO in promoting decentralization reform in Ukraine are highlighted. Attention is paid to the peculiarities of the formation of administrative-territorial units of the relevant region in compliance with the requirements of the Methodological recommendations on the criteria for the formation of administrativeterritorial units of the subregional 
(district) level. The basic principles of reforming the administrative-territorial structure of the state in the conditions of decentralization in Ukraine are determined.

Key words: decentralization, administrative-territorial system, executive authorities, local self-government, territorial community.

\section{Література}

1. Висновок Головного науково-експертного управління від 02.03.2020 р. на проєкт Закону України «Про засади адміністративно-територіального устрою України» № 2804 вї 24.01.2020 p. URL: https: / / w1.c1.rada.gov.ua/pls / zweb2 / webproc4_1?pf3511=67986.

2. Висновок Головного науково-експертного управління від 18.05.2018 р. на проєкт Закону України «Про засади адміністративно-територіального устроно України» № 8051 від 22.02.2018 p. URL: http: / / w1.c1.rada.gov.ua/pls / zweb2 / webproc4_1?pf3511=63508.

3. Конституиія України від 28.06.1996 р. № $254 \kappa / 96-B P$. URL: https: / / zakon.rada. gov.ua/laws / show / $254 \%$ D0\% BA / 96 $\% D 0 \% B 2 \% D 1 \% 80$.

4. Методичні рекомендації щодо критеріїв формування адміністративно-територіальних одиниць субрегіонального (районного) рівня. Kиїв, 2019. URL: https:// www.minregion.gov.ua/wp-content / uploads/2019/08/Metod.recom_rayon_.pdf.
5. Про затвердження Положення про Міністерство розвитку громад та територій України: постанова Кабінету Міністрів України від 30.04.2014 р., № 197. URL: https: / / zakon.rada.gov.ua/laws / show / 197-2014-\% D0\% BF.

6. Про місиеве самоврядування в Україні: Закон України від 21.05.1997 р. № 280/97BP. URL: https: / / zakon.rada.gov.ua / laws / show / $280 / 97-\%$ D0\% B2\% D1\%80.

7. Про схвалення Концепиії реформування місцевого самоврядування та територіальної організації влади в Україні: розпорядження Кабінету Міністрів України; Кониепиія від 01.04.2014 p. № 333-р. URL: https: / / zakon.rada.gov.ua/laws / show /333-2014-\% D1\%80.

8. Проєкт Закону про засади адміністративно-територіального устрою України № 2804 від 24.01.2020 p. URL: https: / / w1.c1.rada.gov.ua/pls / zweb2 / webproc4_1?pf3511=67986.

9. Проєкт Закону про засади адміністративно-територіального устрою України № 8051 від 22.02.2018 p. URL: http: / / w1.c1.rada.gov.ua/pls / zweb2 / webproc4_1?pf3511=63508.

10. Усі області отримали онлайн-консультації з формування нових районів. URL: https: / / www.minregion.gov.ua / press / news / usi-oblasti-otrymaly-onlajn-konsultacziyi-zformuvannya-novyh-rajoniv/.

11. Швейиарсько-український проєкт «Підтримка децентралізащії в Україні» DESPRO. URL: https://despro.org.ua/ despro/project/. 